BNL-112631-2016-JA

\title{
Cu Deposited on CeOx-Modified TiO2(110): Synergistic Effects at the Metal-Oxide Interface and the Mechanism of the WGS Reaction
}

Jose J. Plata, Jesús Graciani, Jaime Evans, José A. Rodriguez, and Javier Fernández Sanz

Submitted to ACS Catalysis

July 2016

Chemistry Department

Brookhaven National Laboratory

\author{
U.S. Department of Energy \\ USDOE Office of Science (SC), \\ Basic Energy Sciences (BES) (SC-22)
}




\section{DISCLAIMER}

This report was prepared as an account of work sponsored by an agency of the United States Government. Neither the United States Government nor any agency thereof, nor any of their employees, nor any of their contractors, subcontractors, or their employees, makes any warranty, express or implied, or assumes any legal liability or responsibility for the accuracy, completeness, or any third party's use or the results of such use of any information, apparatus, product, or process disclosed, or represents that its use would not infringe privately owned rights. Reference herein to any specific commercial product, process, or service by trade name, trademark, manufacturer, or otherwise, does not necessarily constitute or imply its endorsement, recommendation, or favoring by the United States Government or any agency thereof or its contractors or subcontractors. The views and opinions of authors expressed herein do not necessarily state or reflect those of the United States Government or any agency thereof. 


\title{
Cu deposited on $\mathrm{CeO}_{\mathrm{x}}$-modified $\mathrm{TiO}_{2}(110)$ : Synergistic effects at the metal-oxide interface and the mechanism of the WGS reaction
}

\author{
Jose J. Plata, ${ }^{\dagger \&}$ Jesús Graciani, ${ }^{\&}$ Jaime Evans, ${ }^{\$}$ José A. Rodriguez ${ }^{\#}$ and Javier Fernández Sanz*\& \\ ${ }^{\&}$ Departamento de Química Física, Universidad de Sevilla, Sevilla 41012, Spain \\ ${ }^{s}$ Facultad de Ciencias, Universidad Central de Venezuela, Caracas 1020-A, Venezuela. \\ ${ }^{\#}$ Chemistry Department, Brookhaven National Laboratory, Upton, NY, 11973, USA.
}

\begin{abstract}
Experimental techniques and state-of-the-art DFT calculations have been combined to study the effect of the metalsubstrate interaction in the $\mathrm{Cu} / \mathrm{CeO}_{\mathrm{x}} / \mathrm{TiO}_{2}(110)$ system for the water-gas shift reaction. Experiments demonstrate that $\mathrm{OH}$ groups are easily produce in the $\mathrm{CeO}_{\mathrm{x}} / \mathrm{TiO}_{2}(110)$ and the importance of highly dispersed $\mathrm{Cu}$ clusters in the performance of the catalyst. The apparent activation energy was also calculated and is in agreement with the higher activity of this system compare to other families of catalysts. DFT calculations indicate that $\mathrm{CeO}_{\mathrm{x}}$ are the preferential nucleation sites for the $\mathrm{Cu}$ nanoparticles, improving the dispersion of the metal phase and making available the reservoir of $\mathrm{OH}$ groups dissociated in the $\mathrm{CeO}_{\mathrm{x}}$ clusters. The minimum energy path for the WGS reaction on the new highly active catalytic system $\mathrm{Cu} / \mathrm{CeO}_{\mathrm{x}} / \mathrm{TiO}_{2}(110)$ has been predicted by state-of-theart theoretical calculations. Main steps as adsorption-dissociation of water, and $* \mathrm{OCOH}$ carboxyl intermediate formationdeprotonation have been characterized. In this very particular system, water dissociation is no longer the rate-limiting step since the energy barrier for this process is only $0.04 \mathrm{eV}$. One important insight of the present work is to show that easy full-hydration of the ceria particles strongly lowers the reaction barrier for the deprotonation of the $* \mathrm{OCOH}$ intermediate and facilitates the evolution of the WGS reaction. For the first time, it has been found a system on which the WGS reaction is able to work with all the involved energy barriers below $0.5 \mathrm{eV}$. This extraordinary behavior makes the $\mathrm{Metal} / \mathrm{CeO}_{\mathrm{x}} / \mathrm{TiO}_{2}$ family an outstanding candidate for industrial application as catalysts in the WGS reaction.
\end{abstract}

\section{INTRODUCTION}

In the past years, there has been an increasing global concern about the environmental pollution. A huge research effort has been carried out by the scientific community and by the whole society in the searching for new, clean, and renewable sources of energy. $1,2,3,4,5$ One of the strategies to reach this goal is to use hydrogen as source of energy. The reaction of $\mathrm{H}_{2}$ with $\mathrm{O}_{2}$ in the proper way may produce electricity and just $\mathrm{H}_{2} \mathrm{O}$ as byproduct. However, the regular and massive sources of $\mathrm{H}_{2}$ (usually as a subproduct from the refineries) very often contain $\mathrm{CO}$, which poisons and collapses the fuel cell electrodes. The usual way to remove all $\mathrm{CO}$ from the $\mathrm{H}_{2}$ source is by coupling a reactor containing $\mathrm{H}_{2} \mathrm{O}$ steam and a convenient catalyst to foster the so-called water-gas shift reaction (WGS): $\mathrm{H}_{2} \mathrm{O}+\mathrm{CO} \rightarrow \mathrm{H}_{2}+\mathrm{CO}_{2}$, in which $\mathrm{CO}$ is removed and more $\mathrm{H}_{2}$ is produced. ${ }^{3,4,5,6,7}$ This purified source of $\mathrm{H}_{2}$ is then introduced in the fuel cell.

The WGS reaction has received much attention due to its important technological applications. Many catalytic systems, usually based on metal particles supported on an oxide, have been studied from theory and experiment, to improve the performance of the WGS reaction., ${ }^{3,4,6,7,7,8,9,10,11,12,13,14,15}$ The main conclusion from those studies is that the WGS catalyst is bi-functional: a metal phase (usually supported nanoparticles) is needed for $\mathrm{CO}$ adsorption, ${ }^{16,17,18,19}$ while a reducible oxide phase (usually $\mathrm{TiO}_{2}$ or $\mathrm{CeO}_{2}$ ) is necessary for the adsorption and dissociation of water. ${ }^{20,21,22,23,24}$ There are some exceptions to this usual behavior. For instance, it has been found that the barrier for water dissociation in $\mathrm{Ni} / \mathrm{CeO}_{\mathrm{x}}$ is also very low in the metal $(2.3 \mathrm{kcal} / \mathrm{mol}){ }^{25}$ Low stable intermediates, which easily evolve to products, would be formed at the interface, avoiding the formation of the high stable intermediates, which stop the reaction (observed usually on the pure oxide) ${ }^{20}$ It is interesting to note that neither pure metal, ${ }^{26,27}$ nor 
pure oxide can carry out by itself the WGS reaction in an effective way, ${ }^{20}$ but together they achieve great activity, being present therefore a remarkable synergy between them. Thus, to optimize the activity of a metal/oxide WGS catalyst, one must improve the performance of both the metal and oxide phases.

There is an extensive literature about the effect of the reducibility of the oxide and the presence of reduced $\mathrm{M}^{3+}$ in the catalytic activity of the sample. In the case of $\mathrm{CeO}_{2}$, a direct correlation between the amount of reduced species $\mathrm{Ce}^{3+}$ and the WGS catalytic activity has been found, ${ }^{20}$ showing the importance of the reducibility of the oxide for the dissociation of water ${ }^{20,21,23,28,29,30,31,32,33}$ and, in general, for the reactivity of $\mathrm{CeO}_{2}$ surfaces. ${ }^{34}$ However, some new findings suggest that the capacity to form oxygen vacancies is not the main reason of the activity of these catalysts. ${ }^{35}$ Recently, some papers by Rodriguez et al. have shown, from experiment ${ }^{22,36,37}$ and theory, ${ }^{38}$ a new generation of highly active WGS-catalysts, in which the amount of the active reduced species $\mathrm{Ce}^{3+}$ on the surface of the support is highly increased with respect to the conventional oxide supports. This new oxide phase consists of a mixed-metal oxide at the nanometer level: really small $\mathrm{CeO}_{\mathrm{x}}$ particles (in fact dimers) are formed on the $\mathrm{TiO}_{2}$ surface, being the interaction between them so high that the geometric and electronic properties of the $\mathrm{CeO}_{\mathrm{x}}$ particles are strongly modified, increasing the reducibility of $\mathrm{Ce}$, and consequently improving the catalytic activity. Moreover, it has been experimentally shown that the presence of the $\mathrm{CeO}_{\mathrm{x}}$ particles on the $\mathrm{TiO}_{2}$ surface increases the dispersion and the resistance to the thermal agglomeration of the metal particles on the $\mathrm{TiO}_{2}$ surface pointing to a $\mathrm{CeO}_{\mathrm{x}}$-induced higher metal-support interaction. ${ }^{36}$ This strong metal-support interaction decreases the size of the metal particles, increasing thus the catalytic activity. The performance of different metal particles on these new catalytic systems, show the sequence $\mathrm{Pt} \approx \mathrm{Cu}>>\mathrm{Au}$ (Figure 1). ${ }^{36} \mathrm{The}_{\mathrm{CeO}} / \mathrm{TiO}_{2}$ system clearly displays a superior performance with respect to plain $\mathrm{TiO}_{2}$. Among the supported metals, platinum is only slightly more active than copper, being copper a truly non-expensive metal. Therefore, $\mathrm{Cu}$ is a very good candidate as metal phase for these catalytic systems when considering the possibility of an industrial-massive production.

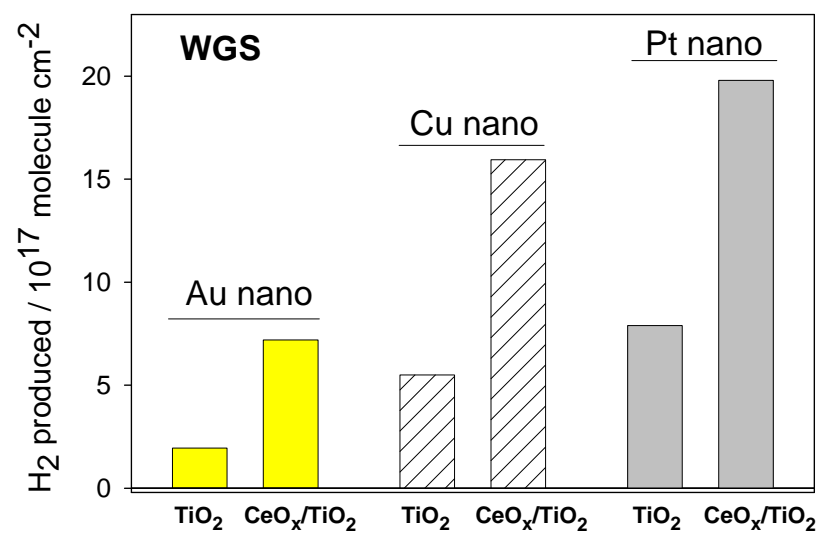

Figure 1. Amount of $\mathrm{H}_{2}$ produced by the WGS reaction on catalysts generated by depositing 0.15 monolayer of $\mathrm{Au}, \mathrm{Cu}$ or $\mathrm{Pt}$ on $\mathrm{CeO}_{\mathrm{x}} / \mathrm{TiO}_{2}(110)$ surfaces in which $12-14 \%$ of the titania was pre-covered with $\mathrm{CeO}_{x}$ nanoparticles. For comparison, data for the deposition of the metals on plain $\mathrm{TiO}_{2}(110)$ is also included. The reported values for the production of $\mathrm{H}_{2}$ were collected after exposing the catalysts to 20 Torr of $\mathrm{CO}$ and $10 \mathrm{Torr}$ of $\mathrm{H}_{2} \mathrm{O}$ at $625 \mathrm{~K}$ for 5 minutes. Reprinted with permission from ref. 36. Copyright 2010 American Chemical Society.

The previous study for the $\mathrm{Cu} / \mathrm{CeO}_{\mathrm{x}} / \mathrm{TiO}_{2}(110)$ system had a limited scope, ${ }^{34}$ and many fundamental questions remain unsolved. It seems that the nature of the metal substrate interaction is the key because of the different size and morphology of the metal nanoparticles compared to other catalysts. However, the explanation for this behavior and its implications in the catalytic cycle are completely unclear. Questions about the nature of the metal-support interaction, the influence of that interaction in the geometry and electronic structures of the metal particles and, more interestingly, the reaction pathway on these new systems (including the nature and stability of the intermediates), have to be addressed in order to rationalize the performance of this catalyst and the future design of new catalyst with higher activity. The purpose of the present work is to understand the influence of the metal-support interaction in the catalytic activity of the $\mathrm{Cu} / \mathrm{CeO}_{\mathrm{x}} / \mathrm{TiO}_{2}$ system combining a series of experimental studies and state-of-the-art DFT calculations.

\section{EXPERIMENTAL AND THEORETICAL METHODS}

The $\mathrm{Cu} / \mathrm{CeO}_{\mathrm{x}} / \mathrm{TiO}_{2}(110)$ catalysts were studied in a set-up that combines a Ultra-High Vacuum (UHV) chamber for surface characterization (base pressure $\sim 5 \times 10^{-10}$ Torr) and a batch reactor for catalytic tests. ${ }^{11,22,34}$ The sample could be transferred between the reactor and the UHV chamber without exposure to air. The UHV chamber was equipped with instrumentation for x-ray photoelectron spectroscopy (XPS), ultraviolet photoelectron spectroscopy (UPS), low-energy electron diffraction (LEED), ion-scattering spectroscopy (ISS), and thermal-desorption mass spectroscopy (TDS). ${ }^{12,22,34}$ The $\mathrm{Cu} / \mathrm{TiO}_{2}(110)$ and $\mathrm{Cu} / \mathrm{CeO}_{\mathrm{x}} / \mathrm{TiO}_{2}(110)$ were prepared following the methodology described in references ${ }^{22,34}$. For both type of catalysts the copper coverage was changed in a systematic way.

In the catalytic tests, the sample was transferred to the reactor at $\sim 300 \mathrm{~K}$, then the reactant gases, 20 Torr of $\mathrm{CO}_{2}$ and $10 \mathrm{Torr}$ of $\mathrm{H}_{2} \mathrm{O},{ }^{11,22,34}$ were introduced and the sample was rapidly heated to the reaction temperatures $(500-625 \mathrm{~K})$. Product yields were analyzed by a mass spectrometer and/or a gas chromatograph. ${ }^{11,22,34}$ The amount of molecules $\left(\mathrm{H}_{2}\right.$ or $\left.\mathrm{CO}_{2}\right)$ produced in the catalytic tests was normalized by the active area exposed by the sample and the total reaction time. The kinetic experiments were done in the limit of low conversion $(<$ $5 \%$.

The DFT calculations were performed using the plane-wave-pseudopotential approach within the projector augmented wave method (PAW) ${ }^{39}{ }^{40}$ together with the GGA exchange correlation functional proposed by Perdew et al. ${ }^{41}$ (PW91) as implemented in the VASP 4.6 code. ${ }^{42,43}$ A plane-wave cutoff energy of $400 \mathrm{eV}$ was used. We treated the Ti (3s, 3p, 3d, 4s), Ce (4f, 5s, 5p, 5d, 6s), 
$\mathrm{Cu}(3 \mathrm{~d}, 4 \mathrm{~s}), \mathrm{Ag}(4 \mathrm{~d}, 5 \mathrm{~s}), \mathrm{Au}(5 \mathrm{~d}, 6 \mathrm{~s}), \mathrm{Pt}(5 \mathrm{~d}, 6 \mathrm{~s})$ and $\mathrm{O}(2 \mathrm{~s}, 2 \mathrm{p})$ electrons as valence states, while the remaining electrons were kept frozen as core states. To obtain faster convergence, thermal smearing of one-electron states $\left(\mathrm{k}_{\mathrm{B}} \mathrm{T}=0.05 \mathrm{eV}\right)$ was allowed using the Gaussian smearing method to define the partial occupancies. The energy was estimated at the gamma point.

We chose a (6x2) surface model with the aim to have isolated $\mathrm{CeO}_{\mathrm{x}}$ dimers and metal clusters on the $\mathrm{TiO}_{2}(110)$ surface $($ see Figure 2). The slab was 12 atomic layers thick or four $\mathrm{TiO}_{2}$-trilayers, as it is known that thicker supercell models gave comparable results in a similar study ${ }^{44}$ In all cases, the two lower $\mathrm{TiO}_{2}$ trilayers were kept frozen while the rest of the atoms were allowed to fully relax their atomic positions (see Figure 2). The supercell slab model is separated from their images by a vacuum of $15 \AA$, considered enough to avoid interaction between the slabs. For building the supercell model we used the optimized lattice parameters for the bulk $\mathrm{a}=4.1616 \AA, \mathrm{c}=2.974 \AA$, and $\mathrm{u}=0.304 \AA$. On the nomenclature used to call the surface atoms see Figure 2c.

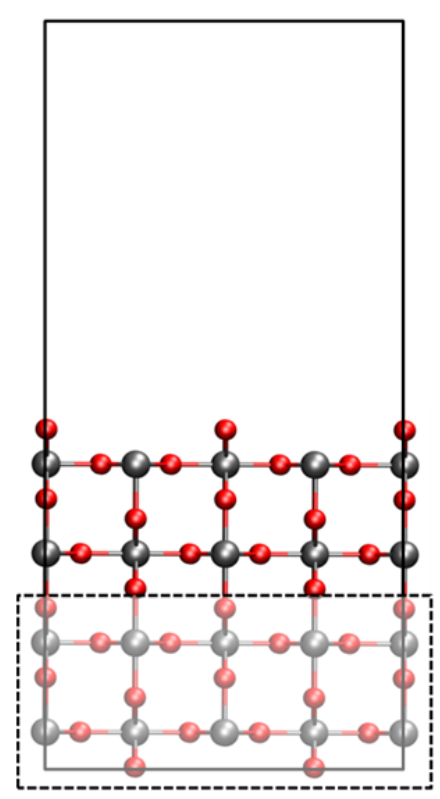

(a)

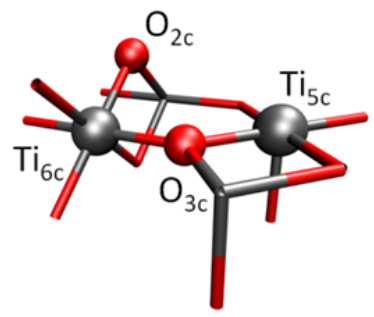

(c)

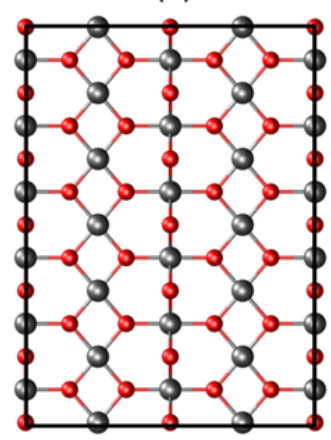

(b)

Figure 2. Supercell slab model used for representing the $\mathrm{TiO}_{2}(110)$ surface. (a) Side view. The solid line indicates the supercell and the dashed line shows the atoms kept fixed at their bulk positions. (b) Top view of the supercell, showing the 6x2 surface cell. (c) Different atoms present in the $\mathrm{TiO}_{2}(110)$ surface.

In order to represent adequately the electronic structure of $\mathrm{Ce}$ (in particular the $4 \mathrm{f}$ level of the $\mathrm{Ce}^{3+}$ species) we used the $\mathrm{GGA}+\mathrm{U}$ formalism. The Hubbard U term was added to the plain GGA functional employing the rotationally invariant approach proposed by Dudarev et al., ${ }^{45}$ in which the Coulomb U and exchange J parameters are combined into a single parameter U $\mathrm{eff}=\mathrm{U}-\mathrm{J}$. For Ce we have used the $\mathrm{U}_{\text {eff }}$ of $4.5 \mathrm{eV}$ which was self-consistently calculated by Fabris et al. ${ }^{46}$ using the linear-response approach of Cococcioni and de Gironcoli ${ }^{47}$ and which is in the range of values usually proposed in the literature $(4.5-5.5 \mathrm{eV})$ for $\mathrm{GGA}+\mathrm{U}$ calculations. ${ }^{48,49,50,51,52,53,54,55,56}$ For the $3 \mathrm{~d}$ states of $\mathrm{Ti}$ we also chose a $\mathrm{U}_{\text {eff }}$ parameter of $4.5 \mathrm{eV}$ as it reproduces the experimental values of the gap between the $\mathrm{Ce}^{3+} 4 \mathrm{f}_{\text {and }} \mathrm{Ti}^{3+} 3 \mathrm{~d}$ levels observed in the valence photoemission spectra of $\mathrm{Ce} / \mathrm{TiO}_{2}(110)$ system. ${ }^{22}$ Although lower values for $\mathrm{U}_{\text {eff }}$ have also been proposed for a balanced description of bulk $\mathrm{CeO}_{2}$ and $\mathrm{Ce}_{2} \mathrm{O}_{3}$ oxides, ${ }^{57,58}$ the set of parameters we have selected allows for a correct description of the gaps observed in the experimental photoemission spectra of our systems consisting of $\mathrm{CeO}_{x}$ clusters supported on the $\mathrm{TiO}_{2}(110)$ surface. ${ }^{22}$ The presence of $\mathrm{Ce}^{3+}$ species was indicated by a characteristic $4 \mathrm{f}$ peak in the band gap and later confirmed by the magnetization of the Ce atoms (higher than 0.9 electrons) found in the calculations. In the same way the presence of $\mathrm{Ti}^{3+}$ species was indicated by a characteristic $3 \mathrm{~d}$ peak in the band gap and later confirmed by the magnetization of the Ti atoms (higher than 0.8 electrons) found in the calculations. These $\mathrm{U}_{\text {eff }}$ parameters for Ce and $\mathrm{Ti}$ have been used successfully for the $\mathrm{CeO}_{\mathrm{x}} / \mathrm{TiO}_{2}(110)$ systems in previous papers ${ }^{22,36,38}$

The adsorption energy for a given species $\mathrm{X}$, (where $\mathrm{X}$ stands for metal cluster, $\mathrm{H}_{2} \mathrm{O}, \mathrm{CO}$, etc.) has been calculated as:

$$
\mathrm{E}_{\text {ads }}(\mathrm{X})=\mathrm{E}\left(\mathrm{X} / \mathrm{CeO}_{\mathrm{x}} / \mathrm{TiO}_{2}\right)-\mathrm{E}(\mathrm{X})-\mathrm{E}\left(\mathrm{CeO}_{\mathrm{x}} / \mathrm{TiO}_{2}\right) \text { Where } \mathrm{E}_{\mathrm{ads}}(\mathrm{X}) \text { is the adsorption energy of } \mathrm{X} \text { on } \mathrm{CeO}_{\mathrm{x}} / \mathrm{TiO}_{2}(110) \text {, }
$$
$\mathrm{E}\left(\mathrm{X} / \mathrm{CeO}_{\mathrm{x}} / \mathrm{TiO}_{2}\right)$ is the total energy of the system in which $\mathrm{X}$ is adsorbed on the $\mathrm{CeO}_{\mathrm{x}} / \mathrm{TiO}_{2}(110)$ surface, $\mathrm{E}(\mathrm{X})$ is the energy of the isolated $\mathrm{X}$ species and $\mathrm{E}\left(\mathrm{CeO}_{\mathrm{X}} / \mathrm{TiO}_{2}\right)$ is the energy of the slab model of the surface consisting of a $\mathrm{Ce}_{2} \mathrm{O}_{3}$ dimer deposited on 
$\mathrm{TiO}_{2}(110)$. For more details of the structure of the $\mathrm{CeO}_{\mathrm{x}} / \mathrm{TiO}_{2}(110)$ see Ref. 22,36,38. Obviously, when the molecules $\mathrm{H}_{2} \mathrm{O}$ or $\mathrm{CO}$ are adsorbed on the $\mathrm{Metal} / \mathrm{CeO}_{\mathrm{x}} / \mathrm{TiO}_{2}$ system, the calculation of the adsorption energy is modified accordingly:

$\mathrm{E}_{\text {ads }}(\mathrm{X})=\mathrm{E}\left(\mathrm{X} / \mathrm{M} / \mathrm{CeO}_{\mathrm{x}} / \mathrm{TiO}_{2}\right)-\mathrm{E}(\mathrm{X})-\mathrm{E}\left(\mathrm{M} / \mathrm{CeO}_{\mathrm{x}} / \mathrm{TiO}_{2}\right)_{\text {Where }} \mathrm{E}_{\mathrm{ads}}(\mathrm{X})$ is the adsorption energy of $\mathrm{X}$ on Metal $/ \mathrm{CeO}_{\mathrm{x}} / \mathrm{TiO}_{2}(110), \mathrm{E}\left(\mathrm{X} / \mathrm{M} / \mathrm{CeO}_{\mathrm{x}} / \mathrm{TiO}_{2}\right)$ is the total energy of the system in which $\mathrm{X}$ is adsorbed on the $\mathrm{M} / \mathrm{CeO}_{\mathrm{x}} / \mathrm{TiO}_{2}(110)$ surface, $\mathrm{E}(\mathrm{X})$ is the energy of the isolated $\mathrm{X}$ species and $\mathrm{E}\left(\mathrm{M} / \mathrm{CeO}_{\mathrm{X}} / \mathrm{TiO}_{2}\right)$ is the energy of the slab model of the surface consisting of a metal cluster and a $\mathrm{Ce}_{2} \mathrm{O}_{3}$ dimer on $\mathrm{TiO}_{2}(110)$.

Transitions states have been calculated by using the climbing image version of the nudged elastic band (NEB) algorithm ${ }^{59}$ and in all cases, after a vibrational analysis, a single imaginary frequency has been obtained for these structures.

\section{RESULTS AND DISCUSSION}

\section{Adsorption and dissociation of water.}

The rate determining step for the WGS reaction on clean copper surfaces is the dissociation of water. ${ }^{23,24}$ Figure 3 shows the enhancement in the formation of surface $\mathrm{OH}$ groups when going from $\mathrm{Cu}(111)$ to $0.4 \mathrm{monolayers} \mathrm{(ML)} \mathrm{of}$ copper supported on $\mathrm{TiO}_{2}(110)$ or on a $\mathrm{CeO}_{\mathrm{x}} / \mathrm{TiO}_{2}(110)$ surface $\left(\theta_{\mathrm{Ce}} \sim 0.1 \mathrm{ML}\right)$. On the extended surface of copper, using $\mathrm{XPS}$, we did not detect the deposition of $\mathrm{OH}$ groups after dosing 5 langmuir (L) of water at $300 \mathrm{~K}$, in

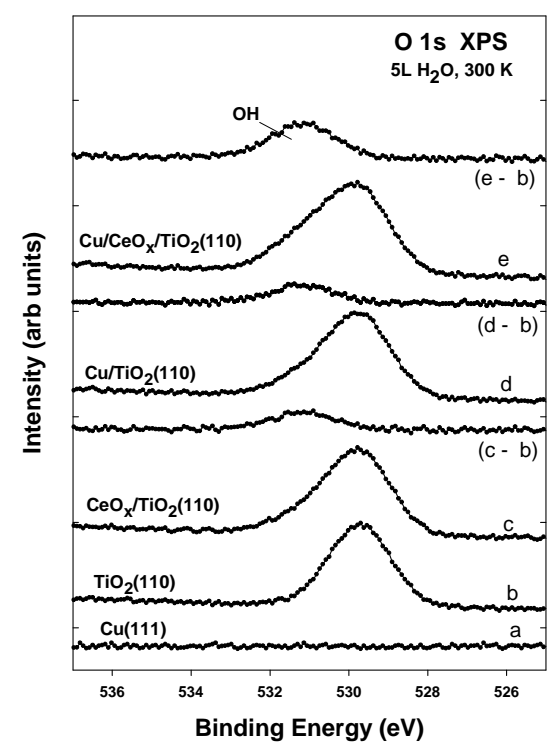

Figure 3. $\mathrm{O}$ 1s XPS spectra collected after dosing $5 \mathrm{~L}$ of water at $300 \mathrm{~K}$ to $\mathrm{Cu}(111), \mathrm{TiO}_{2}(110), \mathrm{Cu}^{\mathrm{TiO}} \mathrm{T}_{2}(110), \mathrm{CeO}_{\times} / \mathrm{TiO}{ }_{2}(110)$, and $\mathrm{Cu} / \mathrm{CeO}_{x} / \mathrm{TiO}_{2}(110) . \theta_{\mathrm{C} 4} \sim 0.4 \mathrm{ML}, \theta_{\mathrm{Ce}} \sim 0.1 \mathrm{ML}$.

agreement with previous studies. ${ }^{23,24}$ As shown in Figure 3, the $\mathrm{Cu} / \mathrm{TiO}_{2}(110)$ system dissociates water better than $\mathrm{Cu}(111)$ or $\mathrm{TiO}_{2}\left(110\right.$, but an even larger rate of $\mathrm{OH}$ formation is seen for the $\mathrm{Cu} / \mathrm{CeO}_{\mathrm{x}} / \mathrm{TiO}_{2}(110)$ surface. In Figure 3 , the $\mathrm{O} 1 \mathrm{~s}$ features near $531.5 \mathrm{eV}$, which correspond to adsorbed $\mathrm{OH}^{23,24}$ are much more intense for $\mathrm{Cu}^{2} \mathrm{CeO}_{\mathrm{x}} / \mathrm{TiO} \mathrm{O}_{2}(110)$ than for any other surface in the graph. In this aspect, there is a clear synergy between the supported copper and ceria. It is known that the barrier for water dissociation on $\mathrm{CeO}_{x} / \mathrm{TiO}_{2}(110)$ is very close to zero. ${ }^{36}$ As we will see below, the same is valid for $\mathrm{Cu} / \mathrm{CeO}_{x} / \mathrm{TiO}_{2}(110)$. In principle, the water molecules could dissociate on sites of ceria or on the ceria-copper interface. Then, the surface species could migrate to the copper particles producing a reservoir of OH groups on the surface. These $\mathrm{OH}$ groups are ready for reaction with $\mathrm{CO}$ and the production of hydrogen through the WGS reaction.

\section{Catalytic activity of $\mathrm{Cu} / \mathrm{CeO}_{\mathrm{x}} / \mathrm{TiO}_{2}$ and $\mathrm{Cu}$ coverage effects.}

Figure 4 shows a systematic comparison of the catalytic activity of the $\mathrm{Cu} / \mathrm{TiO}_{2}(110)$ and $\mathrm{Cu} / \mathrm{CeO}_{\mathrm{x}} / \mathrm{TiO}_{2}(110)\left(\theta_{\mathrm{Ce}} \sim 0.1 \mathrm{ML}\right)$ catalysts as a function of copper coverage. The bare oxide substrates do not exhibit any catalytic activity until copper is deposited. Then, the rates for the production of $\mathrm{H}_{2}$ and $\mathrm{CO}_{2}$ increase until a maximum is found at a copper coverage of 0.4-0.5 ML. After that, there is a continuous decrease in the catalytic activity. Small copper particles dispersed on a $\mathrm{CeO}_{\mathrm{x}} / \mathrm{TiO}_{2}(110)$ substrate display optimum performance. At the peak of maximum activity the $\mathrm{Cu} / \mathrm{CeO}_{\mathrm{x}} / \mathrm{TiO}_{2}(110)$ system is $\sim 3$ times better than $\mathrm{Cu} / \mathrm{TiO} 2(110)$. 


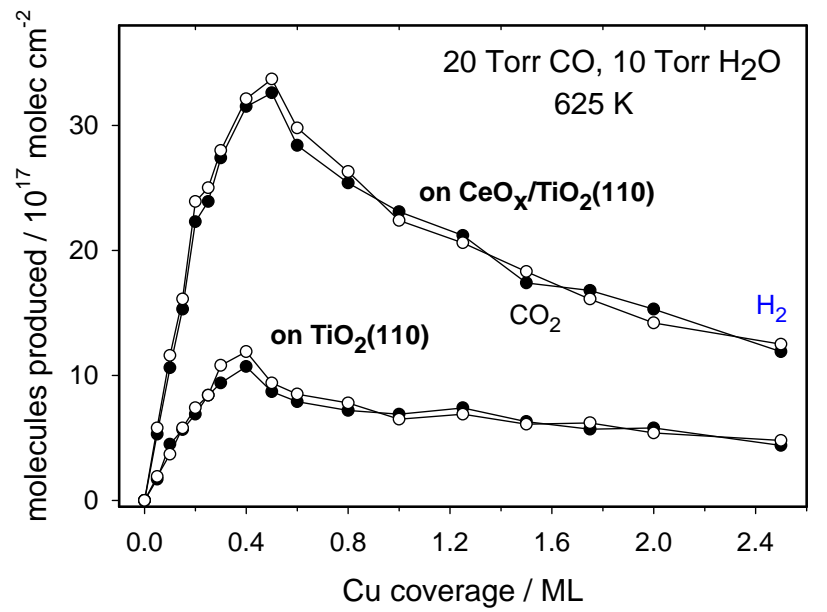

Figure 4. $\mathrm{CO}_{2}$ and $\mathrm{H}_{2}$ production at different $\mathrm{Cu}$ coverages for $\mathrm{Cu} / \mathrm{TiO}_{2}(110)$ and $\mathrm{Cu} / \mathrm{CeO}_{\mathrm{x}} / \mathrm{TiO}_{2}(111)$ catalysts. $\mathrm{P}(\mathrm{CO})=20 \mathrm{Torr} ; \mathrm{P}\left(\mathrm{H}_{2} \mathrm{O}\right)=10 \mathrm{Torr}, \mathrm{T}=625$ $\mathrm{K}, 5$ minutes of reaction.

Figure 5 shows Arrhenius plots for the rate of hydrogen production on $\mathrm{Cu} / \mathrm{TiO}_{2}(110)$ and $\mathrm{Cu} / \mathrm{CeOx} / \mathrm{TiO}{ }_{2}(110)$ catalysts which have a coverage of $0.4 \mathrm{ML}$ of copper. For comparison we add previous results for two common standards in studies of the WGS reaction, $\mathrm{Cu}(111)$ and $\mathrm{Cu}(100) .^{23,26,60,61}$ In the range of temperatures investigated, $\mathrm{Cu} / \mathrm{CeOx} / \mathrm{TiO}_{2}(110)$ is by far the best catalysts. The apparent activation energy for the WGS process decreases from $18 \mathrm{kcal} / \mathrm{mol}$ on $\mathrm{Cu}(111)$ to $10 \mathrm{kcal} / \mathrm{mol} \mathrm{on} \mathrm{Cu} / \mathrm{TiO} 2(110)$ and 7 $\mathrm{kcal} / \mathrm{mol}$ on $\mathrm{Cu} / \mathrm{CeOx} / \mathrm{TiO}_{2}(110)$. There is a clear correlation between the

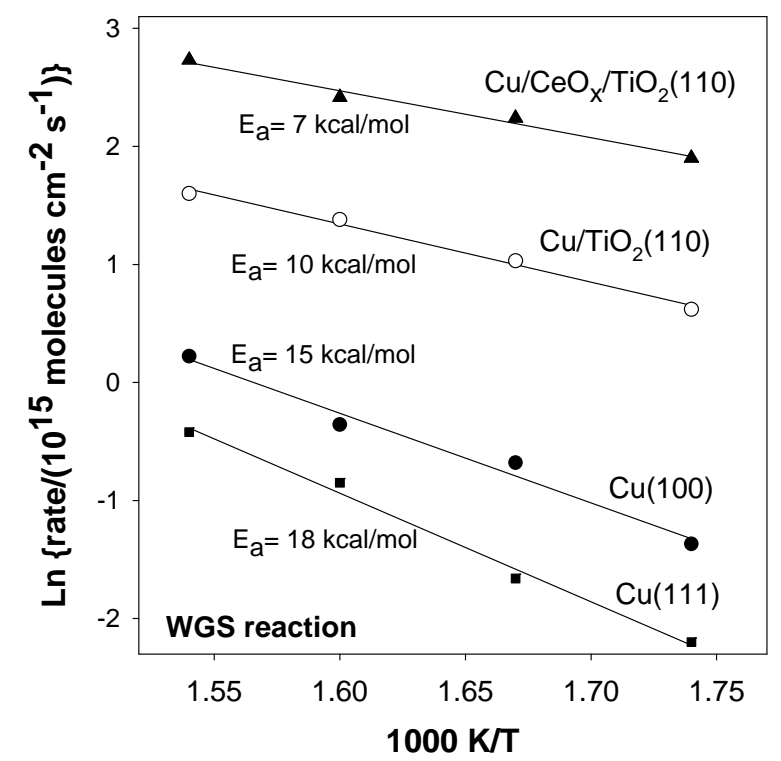

Figure 5. Arrhenius plots for rate of production of hydrogen through the WGS reaction on $\mathrm{Cu} / \mathrm{CeOx} / \mathrm{TiO}_{2}(110), \mathrm{Cu} / \mathrm{TiO} \mathrm{O}_{2}(110), \mathrm{Cu}(100)$ and $\mathrm{Cu}(111)$. $\mathrm{P}(\mathrm{CO})=20$ Torr; $\mathrm{P}(\mathrm{H} 2 \mathrm{O})=10$ Torr.

increase in the rate of water dissociation seen in Figure 3 and the drop in apparent activation energy shown in Figure 5. Bellow this correlation will be explained in detail using DFT calaculations.

To understand the outstanding catalytic activity of the $\mathrm{Cu} / \mathrm{CeO}_{\mathrm{x}} / \mathrm{TiO}_{2}(110)$ system is important to compare it with previous generations of $\mathrm{Cu}$ based catalyst (see Figure 6). $\mathrm{Cu} / \mathrm{CeO}_{\mathrm{x}} / \mathrm{TiO}_{2}$ is more than three times more active than the previous generation of catalyst based on $\mathrm{Cu}$ supported on different oxides $\left(\mathrm{ZnO}, \mathrm{CeO}_{2} \text { and } \mathrm{TiO}_{2}\right)^{12,23}$ and ten times more active than metallic $\mathrm{Cu}$ based catalysts. This unprecedented activity has been can be linked to a better dispersion of $\mathrm{Cu}$ nanoparticles on the $\mathrm{CeO}_{\mathrm{x}} / \mathrm{TiO}_{2}(110)$ catalyst $^{34}$ but it also reflects synergistic effects at the copper-ceria interface that facilitate the dissociation of water and the transformation of $\mathrm{OH}$ and $\mathrm{CO}$ into $\mathrm{H}_{2}$ and $\mathrm{CO}_{2}$. 


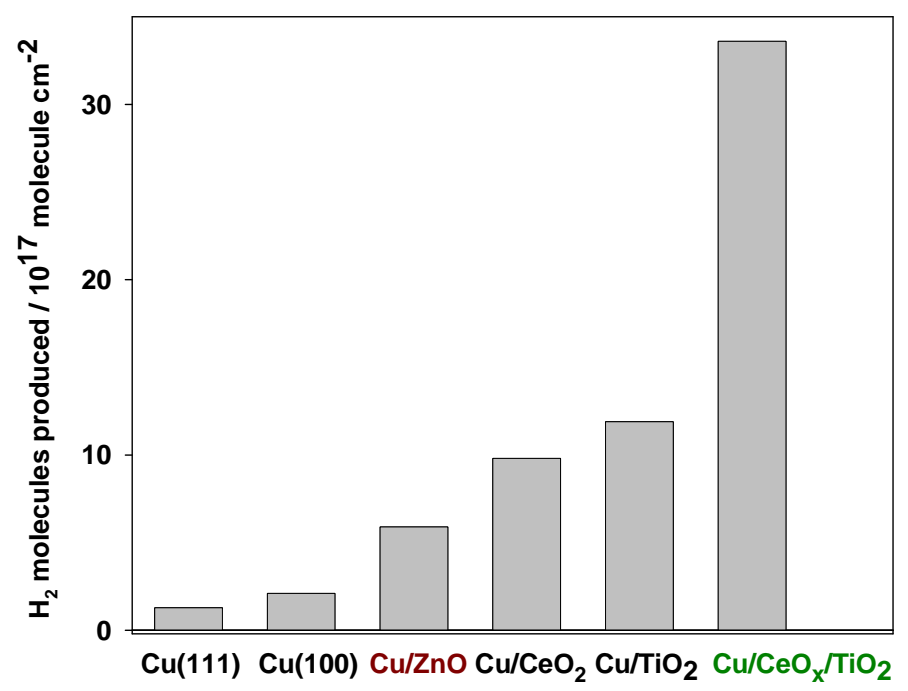

Figure 6. Comparison of the production of molecular hydrogen through the WGS reaction on a series of $\mathrm{Cu}$-containing catalysts. The data for $\mathrm{Cu}(111)$, $\mathrm{Cu}(100), \mathrm{Cu} / \mathrm{ZnO}(000 \overline{1})$ were taken from refs ${ }^{12,23} \cdot \mathrm{P}(\mathrm{CO})=20$ Torr; $\mathrm{P}\left(\mathrm{H}_{2} \mathrm{O}\right)=10$ Torr, $\mathrm{T}=625 \mathrm{~K}, 5$ minutes of reaction.

\section{Adsorption of $\mathrm{Cu}$ nanoclusters on $\mathrm{CeO}_{x}$-modified $\mathrm{TiO}_{2}(110)$}

To model a system similar to the experimental conditions, different $\mathrm{Cu}_{8}$ clusters were adsorbed on the $\mathrm{CeO}_{\mathrm{x}}-\mathrm{modified} \mathrm{TiO}_{2}(110)$ surface. This cluster size is close to the 0.4-0.5 ML coverage on the surface slab and its diameter is below $2 \mathrm{~nm}$. The most stable cluster is $0.93 \mathrm{eV}$ and $2.22 \mathrm{eV}$ more stable than the other models and agrees with the geometry obtained in a previous paper where we analyzed the electronic and catalytic properties of the $\mathrm{Cu} / \mathrm{TiO}_{2}(110)$ catalyst. ${ }^{23}$ It consisted of a $3 \mathrm{D} \mathrm{Cu} \mathrm{u}_{8}$ nanocluster, with a truncated pyramid shape formed by 5 atoms in the layer in contact with the surface. It was found that the $\mathrm{Cu}_{8}$ cluster mainly binds to the $\mathrm{O}$ atoms of the $\mathrm{TiO}_{2}$ surface.

The $\mathrm{Cu}_{8}$ nanocluster was added to the $\mathrm{CeO}_{\mathrm{x}}-\mathrm{TiO}_{2}(110)$ model surface exploring several possible sites, and we found that $\mathrm{Cu}$ clusters adsorb stronger near the $\mathrm{CeO}_{x}$ particles. The adsorption energy at this site is $-3.50 \mathrm{eV}$, while on the perfect surface is of $3.02 \mathrm{eV}$. Moreover, as could be expected since $5 \mathrm{Cu}$ atoms from the 8 of the cluster are in contact with the surface, there is a larger electron transfer $(\sim 1.4 \mathrm{e})$. However, the averaged oxidation state of these $5 \mathrm{Cu}$ atoms is $\mathrm{Q}_{\mathrm{Cu}} \sim 0.3$, the $3 \mathrm{Cu}$ atoms at the top of the metal particle remaining almost neutral. A view of the model is reported in Figure 7.

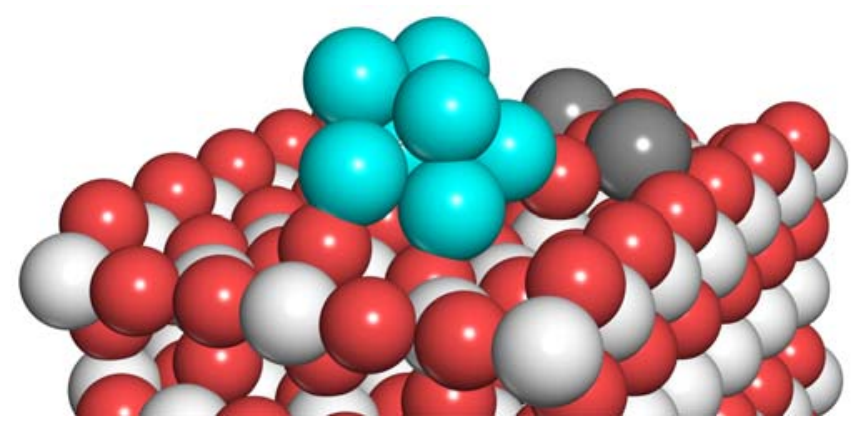

Figure 7. Supercell slab model used for representing the $\mathrm{Cu}$ nanoclusters on $\mathrm{CeO}_{\mathrm{x}}$-modified $\mathrm{TiO}_{2}(110)$ surface. $\mathrm{Ti}$ (white), $\mathrm{O}$ (red), $\mathrm{Cu}$ (blue), $\mathrm{Ce}$ (grey).

\section{Reaction Mechanism for the WGS on $\mathrm{Cu} / \mathrm{CeOx} / \mathrm{TiO} 2$}


Let us now analyze the mechanism for the WGS reaction on the $\mathrm{CeO}_{\mathrm{x}} / \mathrm{TiO}_{2}$ surface. In previous studies Rodriguez et al. have shown that the reaction for a metal/metal-oxide catalyst happens at the metal-titania interface. It has been suggested that it takes place via a carboxyl OCOH intermediate, and involves the steps described in Scheme 1. ${ }^{23}$

Water adsorption is the first step of the mechanism and preconfigures the profile of the catalytic cycle. In principle, because of the high strength of the $\mathrm{OH}$ bond in water, it is assumed that the dissociation of water is the rate limiting step and the most important barrier to overcome. How WGS catalysts could be modified in order to improve adsorption and dissociation of $\mathrm{H}_{2} \mathrm{O}$ has long deserved much attention, and some previous results are reported in Table I for the sake of comparison. Compared to the $\mathrm{Cu}(111)$ surface, ${ }^{62}$ there is an increase of adsorption energy and a decrease of the activation barrier in metal/ $\mathrm{TiO}_{2}{ }^{23,63} \mathrm{catalysts} \mathrm{due}^{2}$ to the easier adsorption of water molecules on oxide vacancies or in areas close to the metal cluster. We have recently characterized $\mathrm{CeO}_{\mathrm{x}}$ nanoparticles on $\mathrm{TiO}_{2}(110)$ surface, which exhibited low coordinated $\mathrm{Ce}^{3+}$ ions ${ }^{.22,36}$ We found that these ions act as active sites where water molecules are adsorbed and then dissociated with almost no apparent barrier $\left(\mathrm{E}_{\mathrm{a}}=0.92 \mathrm{kcal} / \mathrm{mol}\right)$ in a strong exothermic process $(\Delta \mathrm{E}=-16.83 \mathrm{kcal} / \mathrm{mol}){ }^{38}$

$$
\begin{gathered}
\mathrm{H}_{2} \mathrm{O}(\mathrm{g}) \leftrightarrow \mathrm{H}_{2} \mathrm{O}^{*} \\
\mathrm{CO}(\mathrm{g}) \leftrightarrow \mathrm{CO}^{*} \\
\mathrm{H}_{2} \mathrm{O}^{*} \stackrel{\mathrm{TSI(2)} \longrightarrow}{\longrightarrow} \mathrm{OH}^{*}+\mathrm{H}^{*} \\
\mathrm{CO}^{*}+\mathrm{OH}^{*} \stackrel{\mathrm{TS} 3}{\longrightarrow} \mathrm{OCOH}^{*} \\
\mathrm{OCOH}^{*} \stackrel{T S 4}{\longrightarrow} \mathrm{CO}_{2}^{*}+\mathrm{H}^{*} \\
\mathrm{CO}_{2}^{*} \rightarrow \mathrm{CO}_{2}(\mathrm{~g}) \\
2 \mathrm{H}^{*} \rightarrow \mathrm{H}_{2}(\mathrm{~g})
\end{gathered}
$$

Scheme 1. Main steps for the WGS reaction via a $\mathrm{OCOH}$ intermediate.

Table I. Adsorption energy (Eads), activation energy (Ea) and reaction energy $(\Delta E)$ for water dissociation. Second water molecule dissociation are in parenthesis for $\mathrm{Cu} / \mathrm{CeO}_{x} / \mathrm{TiO}_{2}$. Values for the first dissociation are in the presence of the second molecule.

\begin{tabular}{llll}
\hline Catalyst & $\begin{array}{l}\mathrm{E}_{\mathrm{ads}} \\
(\mathrm{kcal} / \mathrm{mol})\end{array}$ & $\begin{array}{l}\mathrm{E}_{\mathrm{a}} \\
(\mathrm{kcal} / \mathrm{mol})\end{array}$ & $\begin{array}{l}\Delta \mathrm{E} \\
(\mathrm{kcal} / \mathrm{mol})\end{array}$ \\
\hline $\mathrm{Cu}(111)^{62}$ & -4.15 & 31.36 & 8.53 \\
$\mathrm{Cu} / \mathrm{TiO}_{2}{\text { (interface })^{63}}^{6}$ & -25.13 & 11.99 & -0.92 \\
$\mathrm{Cu} / \mathrm{TiO}_{2}(\mathrm{vac})^{63}$ & -16.6 & 8.07 & -3.22 \\
$\mathrm{Au} / \mathrm{TiO}_{2}(\text { oxide })^{23}$ & - & 13.84 & 13.83 \\
$\mathrm{Au} / \mathrm{TiO}_{2}(\text { metal })^{23}$ & - & 29.98 & 2.07 \\
$\mathrm{Au} / \mathrm{TiO}_{2}(\text { interface })^{23}$ & - & 12.91 & -2.07 \\
$\mathrm{CeO} 2-\mathrm{x}(111)^{64}$ & -18.45 & 0.92 & -30.9 \\
$\mathrm{CeO}_{\mathrm{x}} / \mathrm{TiO}_{2}{ }^{38}$ & -16.83 & 0.92 & -16.14 \\
$\mathrm{Cu}^{23} \mathrm{CeO}_{\mathrm{x}} / \mathrm{TiO}_{2}$ & -14.99 & $0.92(9.22)$ & $-18.68(0.46)$ \\
\hline
\end{tabular}

The presence of the $\mathrm{Cu}_{8}$ nanocluster does not significantly alter these values, the process being practically barrierless with an adsorption energy of $-14.99 \mathrm{kcal} / \mathrm{mol}$. As can be seen in Figure 8, water molecule adsorbs on top of a Ce ${ }^{3+}$ ion, and since still there is one more $\mathrm{Ce}^{3+}$ ion available we checked adsorption of a second water molecule. This process was also found favorable, the adsorption energy being almost the same than for the first molecule. This is not the case for dissociation energies since while the first dissociation barrier is of only $0.92 \mathrm{kcal} / \mathrm{mol}$ and strongly exothermic, for the second dissociation the activation energy is of $9.91 \mathrm{kcal} / \mathrm{mol}$, and the process is practically thermoneutral. The energy profiles for these steps are gathered in Figure 9. The model shows therefore, that for a $\mathrm{Ce}_{2} \mathrm{O}_{x}$ surface dimer we would find 2 adsorbed water molecule, one of them always dissociated and the other either dissociated or not, with the same likelihood, Figures $\mathbf{8 b}$ and $\mathbf{8 c}$. 

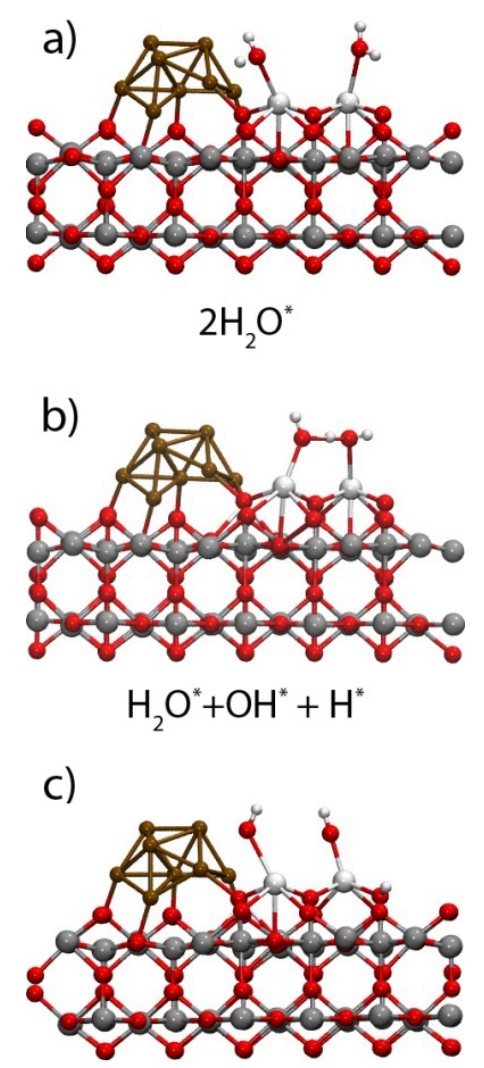

$2 \mathrm{OH}^{*}+2 \mathrm{H}^{*}$

Figure 8. Side view of the supercell model for the adsorption and dissociation of water on the $\mathrm{CeO}_{\mathrm{x}}-$ modified $\mathrm{TiO}_{2}(110)$ surface. (a) $2 \mathrm{H}_{2} \mathrm{O}^{*}$ (b) $\mathrm{H}_{2} \mathrm{O}^{*}+\mathrm{OH}^{*}$ $+\mathrm{H}^{*}$ (c) $2 \mathrm{OH}^{*}+2 \mathrm{H}^{*}$. Ti (grey), $\mathrm{O}$ (red), $\mathrm{Cu}$ (brown), $\mathrm{Ce}$ (white).

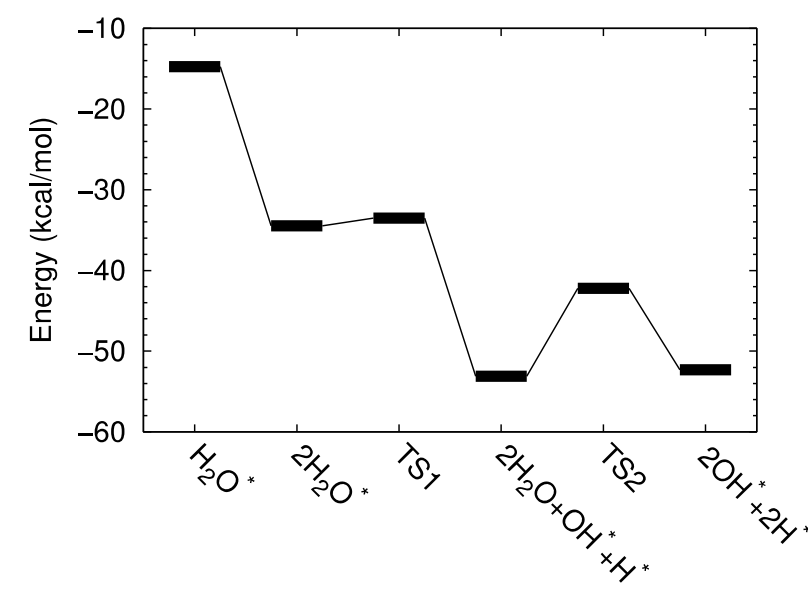

Figure 9. Reaction profile for the adsorption and dissociation of water on the $\mathrm{CeO}_{\mathrm{x}}$-modified $\mathrm{TiO}_{2}(110)$ surface.

Next steps in the mechanism are the $\mathrm{CO}$ adsorption and the formation of the carboxyl intermediate. For $\mathrm{M} / \mathrm{TiO}{ }_{2}$ based catalyst in which the water dissociation barrier is lowered, the formation of OCOH species should become the rate-limiting step, as shown in Table II. Starting from the structure where both water molecules are dissociated, we first adsorb a CO molecule on the catalyst model. One can expect that $\mathrm{CO}$ will preferentially adsorb on low coordinated metal atoms of the cluster, especially in the second layer, edges and corners, so we have combined this fact with positions in which $\mathrm{CO}$ and $\mathrm{OH}$ are close enough to produce carboxyl species (see Figure 10a). The carboxyl species is reached by a shift of an $\mathrm{OH}$ group initially bound to a $\mathrm{Ce}^{3+}$ ion as indicated in Figure 10b. The activation energy obtained is $11.76 \mathrm{kcal} / \mathrm{mol}$, significantly smaller than that reported for the $\mathrm{Cu} / \mathrm{TiO} \mathrm{O}_{2} \mathrm{catalyst}$ $(18.68-20.52 \mathrm{kcal} / \mathrm{mol}){ }^{23,63}$ Moreover this step is only lightly endothermic, which do not penalize the formation of the carboxyl intermediate compared to other catalysts where the reaction is a highly endothermic process (see Table II). The energy profile describing these steps is depicted in Figure 11. On the other hand, after the formation of the carboxyl intermediate, a Ce ${ }^{3+}$ ion is accessible for the adsorption of a new water molecule that could be easily dissociated again. This will be the starting point for the next step in which a deprotonation of the carboxyl intermediate takes place. This step is one of the easier steps in the mechanism, and has been analyzed several times. For $\mathrm{Cu}(111)$, Mavrikakis et al. have reported an activation energy of $9.69 \mathrm{kcal} / \mathrm{mol}$, and the deprotonation was found to be assisted by an hydroxyl group to yield a water molecule. ${ }^{62} \mathrm{In} \mathrm{M} / \mathrm{TiO}_{2}$ type catalyst the values for activation energy fluctuated between 1.15 to $11.53 \mathrm{kcal} / \mathrm{mol}$, and an oxygen atom of the oxide surface also assists the process. In all 
these cases this is not the rate limiting of the reaction. In the present study, for the $\mathrm{Cu} / \mathrm{CeO}_{\mathrm{x}} / \mathrm{TiO}_{2}$ catalyst, we have obtained an activation energy of $8.99 \mathrm{kcal} / \mathrm{mol}$, the step being exothermic by $5.07 \mathrm{kcal} / \mathrm{mol}$. These values grossly agree with the calculations reported for $\mathrm{Cu} / \mathrm{TiO}_{2}(110)$ even though this step was split into two: a first cis-trans isomerization of the carboxyl intermediate, followed by $\mathrm{OH}$ dissociation. Finally, $\mathrm{H}_{2}$ formation and products desorption take place.

Table II. Adsorption energy $\left(E_{\text {ads }}\right)$, activation energy $\left(E_{a}\right)$ and reaction energy $(\Delta E)$ for carboxyl intermediate formation.

\begin{tabular}{llll}
\hline Catalyst & $\begin{array}{l}\mathrm{E}_{\mathrm{ads}} \\
(\mathrm{kcal} / \mathrm{mol})\end{array}$ & $\begin{array}{l}\mathrm{E}_{\mathrm{a}} \\
(\mathrm{kcal} / \mathrm{mol})\end{array}$ & $\Delta \mathrm{E}(\mathrm{kcal} / \mathrm{mol})$ \\
\hline $\mathrm{Cu}(111)^{62}$ & -2.08 & 14.07 & 0.46 \\
$\mathrm{Cu}(\text { cluster })^{65}$ & -13.84 & $\sim 26.52$ & $\sim 23.06$ \\
$\mathrm{Au} / \mathrm{TiO}_{2}{\text { (interface })^{23}}^{23}$ & - & 19.83 & 8.76 \\
$\mathrm{Cu} / \mathrm{TiO}_{2}{\text { (interface })^{23}}^{23}$ & - & 18.68 & 16.14 \\
$\mathrm{Cu} / \mathrm{TiO}_{2}\left(\right.$ interface $^{63}$ & -20.99 & 20.29 & 13.84 \\
& & & \\
$\mathrm{Cu} / \mathrm{CeO}_{\mathrm{x}} / \mathrm{TiO}_{2}$ & -11.53 & 11.76 & 7.35 \\
\hline
\end{tabular}

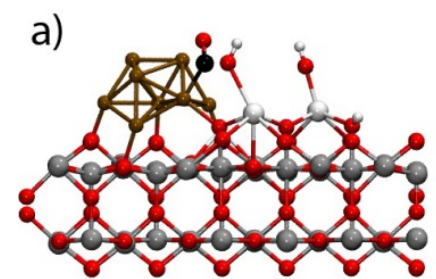

$\mathrm{CO}^{*}+2 \mathrm{OH}^{*}+2 \mathrm{H}^{*}$

b)

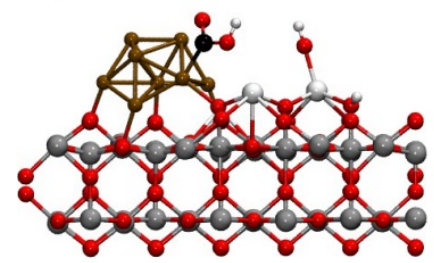

$\mathrm{OCOH}^{*}+\mathrm{OH}^{*}+2 \mathrm{H}^{*}$

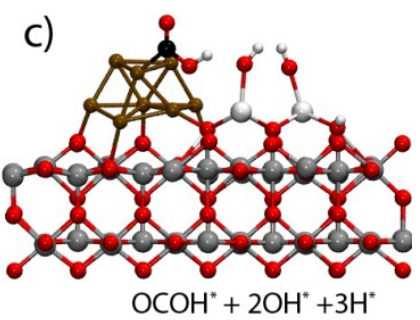

d)

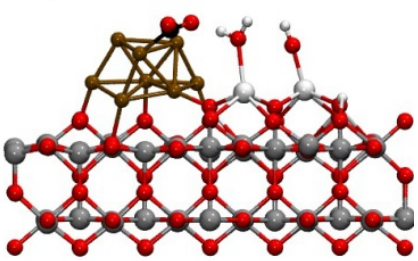

$\mathrm{CO}_{2}{ }^{*}+\mathrm{H}_{2} \mathrm{O}^{*}+\mathrm{OH}^{*}+3 \mathrm{H}^{*}$

Figure 10 Side view of the supercell model for the adsorption of $\mathrm{CO}$ and formation of $\mathrm{CO}_{2}$ via $\mathrm{OCOH}$ intermediate on the $\mathrm{CeO}_{\mathrm{x}}-\mathrm{modified}_{\mathrm{TiO}}(110)$ surface. (a) $\mathrm{CO}^{*}+2 \mathrm{OH}^{*}+2 \mathrm{H}^{*}$ (b) $\mathrm{OCOH}^{*}+\mathrm{OH}^{*}+2 \mathrm{H}^{*}$ (c) $\mathrm{OCOH}^{*}+2 \mathrm{OH}^{*}+3 \mathrm{H}^{*}$ (d) $\mathrm{CO}_{2}{ }^{*}+\mathrm{H}_{2} \mathrm{O}^{*}+\mathrm{OH}^{*}+3 \mathrm{H}^{*}$. Ti (grey), $\mathrm{O}$ (red), $\mathrm{Cu}($ brown), $\mathrm{Ce}$ (white).

The gross energetic changes associated to these steps are also schematized in Figure 11. The energy profile obtained provides an adequate interpretation of previous experimental results, which demonstrates the high performance of this catalyst (Figure 1). ${ }^{36}$ $\mathrm{CeO}_{\mathrm{x}}$ nanoparticles increase adsorption energy, decrease the activation energy for water dissociation and increase the exothermicity of the process. The released energy can be used to overcome the energy barriers for the following steps. The CeO $\mathrm{Cimer}_{\mathrm{x}}$ also facilitates the formation of carboxyl species, because hydroxyls are more accessible to $\mathrm{CO}$ molecules adsorbed on metal cluster. Although the redox mechanism has been identified as preferential in $\mathrm{Pt} / \mathrm{CeO}_{2}$ systems, the characterized microstructure of $\mathrm{Cu} / \mathrm{CeO}_{\mathrm{x}} / \mathrm{TiO}_{2}$ reduces the activation energy for carboxyl formation. All these improvements lead to a reaction pathway in which all barriers are below $11.53 \mathrm{kcal} / \mathrm{mol}$, the lowest value reported as far as we know. Moreover, this value is close to the experimental activation energy $(6.91 \mathrm{kcal} / \mathrm{mol})$. This profile ensures that the reaction can be carried out under mild conditions and low temperatures using one of the most inexpensive noble metals as copper. 


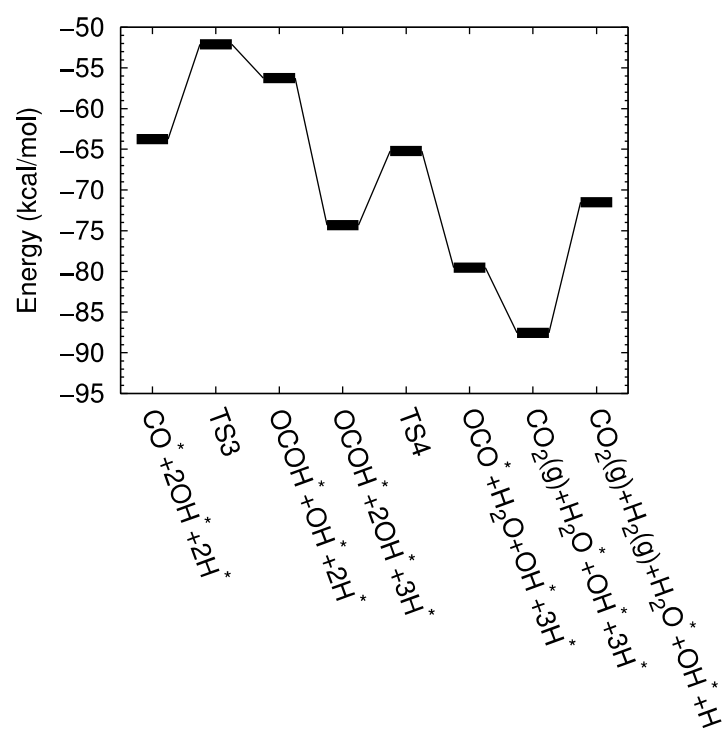

Figure 11. Reaction profile for the adsorption of $\mathrm{CO}$ and formation of $\mathrm{CO}_{2}$ via $\mathrm{OCOH}$ intermediate on the $\mathrm{CeO}_{\mathrm{x}}-\mathrm{modified}_{\mathrm{TiO}}(110) \mathrm{surface}$.

\section{CONCLUSIONS}

In this work we have analyzed the nature of the metal-support interaction of $\mathrm{Cu}$ on $\mathrm{CeO}_{\mathrm{x}}$-modified $\mathrm{TiO}_{2}(110)$ surfaces, and the WGS reaction pathway on the $\mathrm{Cu} / \mathrm{CeO}_{\mathrm{x}} / \mathrm{TiO}_{2}(110)$ three-component catalyst. The $\mathrm{CeO}_{\mathrm{x}}-\mathrm{TiO}_{2}$ interface is an excellent place for the growth of $3 \mathrm{D}$ highly dispersed $\mathrm{Cu}$ particles. $\mathrm{CeO}_{\mathrm{x}}$ partciles acts as preferential nucleation sites for $3 \mathrm{D} \mathrm{Cu}$ clusters.

To elucidate the mechanism of the WGS reaction, we have studied the main steps involved in the whole process: adsorptiondissociation of water and formation-decomposition of the ${ }^{*} \mathrm{OCOH}$ intermediate. We have found that water dissociation is no longer the rate-limiting step in this system, since it has an energy barrier of only $0.92 \mathrm{kcal} / \mathrm{mol}$. On the other hand, we have proposed a reaction path in which all the involved energy barriers are below $11.53 \mathrm{kcal} / \mathrm{mol}$. To the best of our knowledge it is the first time that such a low-barrier path has been found for the water gas shift reaction. The key to get the system working under so low barriers is the hydration/hydroxylation of the cerium oxide particle. This hydration is an exothermic and low barrier process which, furthermore, allows an easy deprotonation of the ${ }^{*} \mathrm{OCOH}$ carboxyl intermediate that finally may lead the reaction to the final products $\mathrm{CO}_{2}$ and $\mathrm{H}_{2}$.

The size and the site of the $\mathrm{Cu}$ cluster, which are determined by the nature of the metal-support interaction, are crucial for the high activity of the system. The preferential growth of the $\mathrm{Cu}$ NPs close to $\mathrm{CeO}_{\mathrm{x}}$ clusters makes possible the absortion of $\mathrm{CO}$ close to the dissociated water moles on top of the $\mathrm{CeO}_{\mathrm{x}}$. Moreover, the preferential 3D shape do not block the $\mathrm{O}_{2 \mathrm{c}}$ on the TiO${ }_{2}$ surface which play an important role in the deprotonation of water molecules and formation of $\mathrm{CO}_{2}$. All these findings may contribute to a deep understanding of the extraordinary catalytic activity of the new family of catalysts $\mathrm{Metal} / \mathrm{CeO}_{\mathrm{x}} / \mathrm{TiO}{ }_{2}$, and may foster further research in order to find new and better WGS reaction catalysts

\section{AUTHOR INFORMATION}

\section{Corresponding Author}

*sanz@us.es

\section{Present Addresses}

$†$ Mechanical Engineering and Materials Science Department, Duke University, Durham, NC, 27705, USA.

\section{Author Contributions}

All authors have given approval to the final version of the manuscript.

\section{Funding Sources}

This work was funded by the Ministerio de Economía y Competitividad (Spain, grant MAT2012-31526) and European FEDER. The work performed at Brookhaven National Laboratory was supported by the U.S. Department of Energy, Office of Science, Office of Basic Energy Sciences, and Catalysis Science Program under contract No. DE-SC0012704.

\section{ACKNOWLEDGMENT}

This work was funded by the Ministerio de Economía y Competitividad (Spain, grants MAT2012-31526 and CSD2008-0023) and European FEDER. Computational resources were provided by the Barcelona Supercomputing Center/Centro Nacional de 
Supercomputación (Spain). The work performed at Brookhaven National Laboratory was supported by the U.S. Department of Energy, Office of Science, Office of Basic Energy Sciences, and Catalysis Science Program under contract No. DE-SC0012704.

\section{REFERENCES}

1 Kruse, N.; Frennet, A.; Bastin, J. M.Top. Catal. 2001, 16-17, 1-449.

2 Webster D. E. Top. Catal. 2001, 16-17, 33.

3 Song, C. Top. Catal. 2008, 49, 1-3.

4 Catalysis by Gold. Edit: Hutchings, G. J.; Goodman, D. W. Top. Catal. 2007, 44.

5 Hutchings, G. J.; Haruta, M. Appl. Catal. A: Gen., 2005, 291, 1.

6 Burch, R. Phys. Chem. Chem. Phys. 2006, 8, 5483.

7 Thinon, O.; Diehl, F.; Avenier, P.; Schuurman, Y. Catal. Today 2008, 137, 29.

8 Haruta, M.; Yamada, N.; Kobayashi, T.; Ijima, S. J. Catal. 1989, 115, 301.

9 Valden, M.; Lai, X.; Goodman, D. W. Science 1998, 281, 1647.

10 Chen M. S.; Goodman, D. W. Science 2004, 306, 252.

11 Fu, Q.; Saltsburg, H.; Flytzani-Stephanopoulos, M. Science 2003, 301, 935.

12 Rodriguez, J. A.; Liu, P.; Hrbek, J.; Evans, J.; Perez, M. Angew. Chem. Int. Ed. 2007, 46, 1329.

13 Guzman, J.; Carrettin, S.; Fierro-Gonzalez, J. C.; Gates, B. C.; Corma, A. Angew. Chem. Int. Ed. $2005,44,4778$.

14 Deng W.; Flytzani-Stephanopoulos, M. Angew. Chem. Int. Ed. 2006, 45, 2285.

15 Si R.; Flytzani-Stephanopoulos, M. Angew. Chem. Int. Ed. 2008, 47, 2884.

16 Chen M. S.; Goodman, D. W. Top. Catal. 2007, 44, 41.

17 Campbell C. T.; Peden, C. H. F. Science 2008, 309, 713.

18 Esch, F.; Fabris, S.; Zhou, L.; Montini, T.; Africh, C.; Fornasiero, P.; Comelli, G.; Rosei, R. Science $2008,309,752$.

19 Torbrügge, S.; Reichling, M.; Ishiyama, A.; Morita, S.; Custance, O. Phys. Rev. Lett. 2007, 99, 056101.

20 Rodriguez, J. A.; Ma, S.; Liu, P.; Hrbeck, J.; Evans, J.; Perez, M. Science 2007, 318, 1757. 
21 Rodriguez, J. A.; Liu, P.; Hrbek, J.; Evans, J.; Perez, M. Angew. Chem. Int. Ed. 2007, 46, 1329.

22 Park, J. B.; Graciani, J.; Evans, J.; Stacchiola, D.; Ma, S.; Liu, P.; Nambu, A.; Sanz, J. F.; Hrbek, J.; Rodriguez, J. A. Proc. Nat. Acad. Sci. 2009, 106, 4975.

23 Rodriguez, J. A.; Evans, J.; Graciani, J.; Park, J. B.; Liu, P; Hrbek, J.; Sanz, J. F. J. Phys. Chem. C 2009, $113,7364$.

24 Rodriguez, J. A.; Graciani, J.; Evans, J.; Park, J. B.; Yang, F.; Stacchiola, D.; Senanayake, S. D.; Ma, S.; Pérez, M.; Liu, P.; Sanz, J. F.; Hrbek, J. Angew. Chem. Int. Ed. 2009, 48, 8047.

${ }^{25}$ Carrasco, J; Lopez-Duran, D.; Liu, Z.; Duchon. T.; Evans, J. Senanayake, S. D.; Crumlin, E. J.; Matolin, V.; Rodriguez, J. A. Ganduglia-Pirovano M. V.; Angew. Chem. Int. ed. 2015, 54, 3917-3921

26 Phatak, A. A.; Delgass, W. N.; Ribeiro, F. H.; Schneider, W. F. J. Phys. Chem. C 2009, 113, 7269.

27 Liu P.; Rodriguez, J. A. J. Chem. Phys. 2007, 126, 164705.

28 Henderson, M. A. Surf. Sci. Rep. 2002, 46, 5.

29 Oviedo, J.; Sanchez-de-Armas, R.; San Miguel, M. A.; Sanz, J. F. J. Phys. Chem. C 2008, 112, 17739.

30 Wu, T.; Kaden, W. E.; Anderson, S. L. J. Phys. Chem. C 2008, 112, 9006.

31 Ketteler, G.; Yamamoto, S.; Bluhm, H.; Andersson, K.; Starr, D. E.; Ogletree, D. F.; Ogasawara, H.; Nilsson, A.; Salmeron, M. J. Phys. Chem. C 2007, 111,8278 .

32 Li, S.-C.; Zhang, Z.; Sheppard, D.; Kay, B. D.; White, J. M.; Du, Y.; Lyubinetsky, I.; Henkelman, G.; Dohnalek, Z. J. Am. Chem. Soc. 2008, 130, 9080.

33 Kajita, S.; Minato, T.; Kato, H. S.; Kawai, M.; Nakayama, T. J. Chem. Phys. 2007, 127, 104709.

34 Trovarelli, A.; Fornasiero, P. Catalysis by Ceria and Related Materials, Imperial College Press, London, 2002; pp 1-908

${ }^{35}$ Vecchietti, J.; Bonivardi, A.; Xu, W.; Stacchiola, D.; Delgado, J. J.; Calatayud, M.; Collins, S. E. ACS Catal. 2015, 4, 2088-2096

36 Park, J. B.; Graciani, J.; Evans, J.; Stacchiola, D.; Senanayake, S. D.; Barrio, L.; Liu, P.; Sanz, J. F.; Hrbek, J.; Rodriguez J. A. J. Am. Chem. Soc. 2010, $132,356$.

37 a) Gonzalez, I.D; Navarro, R.M.; Alvarez-Galvan, M.C.; Rosa, F.; Fierro, J.L.G. Catalysis Communications, 2008, 9, 1759; b) Gonzalez, I.D; Navarro,R.M.; Wen, W.; Marinkovic, N.; Rodríguez, J.A.; Rosa, F.; Fierro, J.L.G. Catal. Today, 2009, $149,372$.

38 Graciani, J.; Plata, J. J.; Sanz, J. F.; Liu, P.; Rodriguez, J. A.; J. Chem. Phys. 2010, 132, 104703.

39 Kresse G.; Joubert, J. Phys. Rev. B 1999, 59, 1758.

${ }^{40}$ Blöchl, P.E. Phys. Rev. B 1994, 50, 17953.

41 Perdew, J.; Chevary, J.; Vosko, S.; Jackson, K.; Pederson, M.; Singh, D.; Fiolhais, C. Phys. Rev. B 1992, $46,6671$.

42 Kresse G.; Hafner, J. Phys. Rev. B 1993, 47, 558. 
43 Kresse G.; Furthmuller, J. Comput. Mater. Sci. 1996, 6, 15-50.

44 Marquez, A. M.; Plata, J. J.; Sanz, J. F. J. Phys. Chem. C 2009, 113, 19973-19980.

45 Dudarev, S. L.; Botton, G. A.; Savrasov, S. Y.; Humphreys, C. J.; Sutton, A. P. Phys. Rev. B 1998, $57,1505$.

46 Fabris, S.; Gironcoli, S.; Baroni, S.; Vicario, G.; Balducci, G. Phys. Rev. B 2005, 72, 237102.

47 Cococcioni M.; Gironcoli, S. Phys. Rev. B 2005, 71, 035105.

48 Castleton, C. W. M.; Kullgren, J.; Hermansson, K. J. Chem. Phys. 2007, 127, 244704.

49 Andersson, D. A.; Simak, S. I.; Johansson, B.; Abrikosov, I. A.; Skorodumova, N. V. Phys. Rev. B 2007, 75, 035109.

50 Nolan, M.; Grigoleit, S.; Sayle, D. C.; Parker, S. C.; Watson, G. W. Surf. Sci. 2005, 576, 217.

51 Nolan, M.; Parker, S. C.; Watson, G. W. Surf. Sci. 2005, 595, 223.

52 Nolan, M.; Parker, S. C.; Watson, G. W. J. Phys. Chem. B 2006, 110, 2256.

53 Watkins, M. B.; Foster, M. B.; Shluger, A. L. J. Phys. Chem. C 2007, 111, 15337.

54 Yang, Z.; Lu, Z.; Luo, G. Phys. Rev. B 2007, 76, 075421.

55 Da Silva, J. L. F. Phys. Rev. B 2007, 76, 193108.

56 Da Silva, J. L. F.; Ganduglia-Pirovano, M. V.; Sauer, J.; Bayer, V.; Kresse, G. Phys. Rev. B 2007, 75, 045121.

57 Loschen, C.; Carrasco, J.; Neyman, K. M.; Illas, F. Phys. Rev. B 2007, 75, 035115.

58 Loschen, C.; Migani, A.; Bromley, S. T.; Illas, F.; Neyman, K. M. Phys. Chem. Chem. Phys. 2008, $10,5730$.

59 Henkelman, G.; Uberuaga, B.; Jonsson, H. J. Chem. Phys. 2000, 113, 9901.

60 Nakamura, J.; Campbell J. M.; Campbell, T.; J. Chem. Soc., Faraday Trans., 1990, 86, 2725-2734

61 Ovesen, C. V.; Stoltze, P.; Norskov, J. K.; Campbell, C. T. J Catal. 1992, 134, 445-468

62 Gokhale, A. A.; Dumesic, J. A.; Mavrikakis, M. J. Am. Chem. Soc. 2008, 130, 1402-1414.

63 Peng, S.; Ho, J. Phys. Chem. Chem. Phys. 2011, 13, 20393-20400.

${ }^{64}$ Marrocchelli D.; Yildiz, B. J. Chem. Phys. C 2012, 116, 2411-2424

${ }^{65}$ Rodriguez, J. A.; Liu, P.; Wang, X.; Wen, W.; Hanson, J.; Hrbek J.; Perez, M.; Evans, J.; Catal. Today 2009, 143, 45 

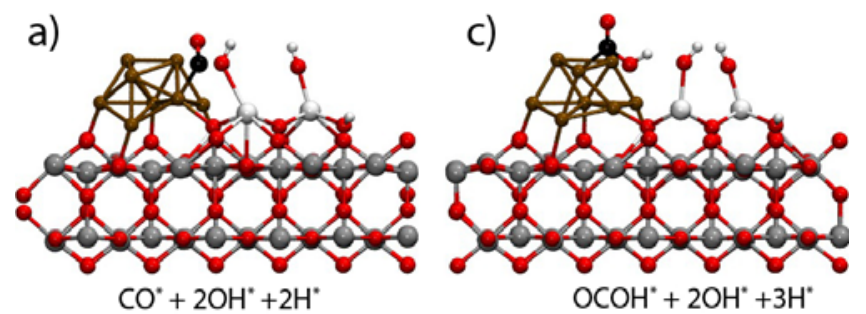

b)

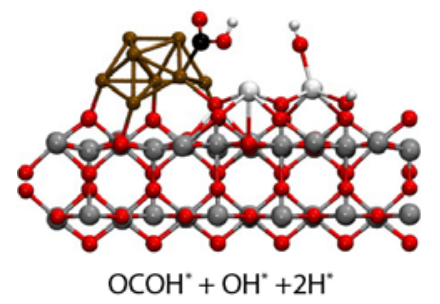

d)

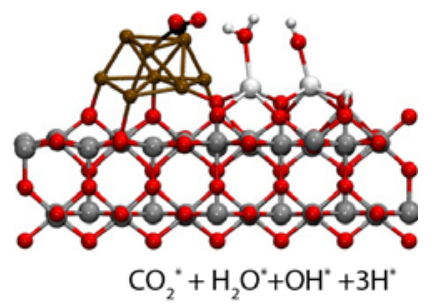

